\title{
Monocyte as a prognostic marker in patients with idiopathic pulmonary fibrosis
}

\author{
Shiping Zhu* (1)
}

\begin{abstract}
This letter raised some concerns about the study by Karampitsakos et al. in a recent issue of Respiratory Research.
\end{abstract}

Keywords: Monocyte, Idiopathic pulmonary fibrosis, Regression model, Mortality

\section{To the Editor,}

We read the interesting study [1] by Karampitsakos et al., which investigated the predictive value of monocyte and red cell distribution width in patients with idiopathic pulmonary fibrosis. In the multivariable regression model, the monocyte and red cell distribution width were converted into dichotomous variables according to their respective cut-off values $(0.6 \mathrm{k} / \mathrm{ul}$ and 14.1$)$. However, after adjusting for confounders, both monocyte and red cell distribution width were not significantly associated with FVC\%pred. We have several concerns about the linear regression model.

First, confounding bias is crucially important in observational studies. However, in the current regression model, the selection of confounding factors seems confusing, as almost all the included factors were nonsignificant except for gender. Second, we noted that the smoker status including current smoker $(n=38)$, ever smoker $(n=199)$ and never smoker $(n=63)$ are mutually exclusive $(38+199+63=300)$. Statistically, these three variables should be included in the regression model as a dummy variable, meaning that one of them is supposed to be the reference level (coefficient $=0$ ). However, in the current model, the coefficients for the current smoker, ever smoker, and never smoker were 19.3, 9.4, and 6.3, respectively. This needs to be verified.

*Correspondence: zsping0908@163.com

Department of Respiratory Medicine, Hangzhou Hospital of Traditional Chinese Medicine, No. 453, Tiyuchang Road, Hangzhou Postal-code:

310000, Zhejiang, China
Third, a total of 14 variables were included in the model for FVC\%pred. However, even some known risk factors (such as age) [2,3] are also non-significant in the model. Therefore, the risk of multicollinearity should be evaluated $[4,5]$, as the presence of multicollinearity can lead to serious statistical problems in parameter estimation, such as non-significant coefficients, high standard errors, or "wrong" sign. Forth, in the Kaplan-Meier survival curve, high monocyte was significantly associated with increased mortality in the derivation cohort while became non-significant in the validation cohort. This result may be affected by the proportion of patients with extremely high monocyte count $(>0.95 \mathrm{k} / \mathrm{ul})$. In another similar study [6] with large sample size $(n=2067)$, all patients were divided into three groups based on monocyte count $(<0.6,0.6-0.95,>0.95 \mathrm{k} / \mathrm{ul})$ and the proportion of patients with extreme high monocyte $(>0.95 \mathrm{k} /$ ul) is very small $(50 / 2067=2.4 \%)$. In the Kaplan-Meier for all-cause mortality (Fig. 1C of Kreuter et al's study), the mortality was significantly higher in the group with extremely high monocyte $(>0.95 \mathrm{k} / \mathrm{ul})$, while it was close in groups with monocyte $<0.6 \mathrm{k} / \mathrm{ul}$ and $0.6-0.95 \mathrm{k} / \mathrm{ul}$. In the validation cohort of the current study, the sample size is small $(n=189)$. Therefore, it is reasonable to conclude that the non-significant mortality rate between low and high monocyte (<0.6 vs. $>0.6 \mathrm{k} / \mathrm{ul}$ ) may be caused by the close mortality rate and low proportion of extremely high monocyte count. original author(s) and the source, provide a link to the Creative Commons licence, and indicate if changes were made. The images or other third party material in this article are included in the article's Creative Commons licence, unless indicated otherwise in a credit line to the material. If material is not included in the article's Creative Commons licence and your intended use is not permitted by statutory regulation or exceeds the permitted use, you will need to obtain permission directly from the copyright holder. To view a copy of this licence, visit http://creativecommons.org/licenses/by/4.0/. The Creative Commons Public Domain Dedication waiver (http://creativecommons.org/publicdomain/zero/1.0/) applies to the data made available in this article, unless otherwise stated in a credit line to the data. 


\section{Abbreviation}

FVC: Forced vital capacity.

\section{Acknowledgements}

None.

\section{Authors' contributions}

SZ designed the study and wrote the manuscript. The author read and approved the final manuscript.

\section{Funding}

None.

Availability of data and materials

Not applicable.

\section{Declarations}

Ethics approval and consent to participate

Not needed.

\section{Consent for publication}

Not applicable.

\section{Competing interests}

The authors declare no competing interests.

Received: 1 September 2021 Accepted: 14 October 2021

Published online: 21 October 2021

\section{References}

1. Karampitsakos T, Torrisi S, Antoniou K, Manali E, Korbila I, Papaioannou O, Sampsonas F, Katsaras M, Vasarmidi E, Papakosta D, et al. Increased monocyte count and red cell distribution width as prognostic biomarkers in patients with Idiopathic Pulmonary Fibrosis. Respir Res. 2021;22:140.

2. Kohansal R, Martinez-Camblor P, Agusti A, Buist AS, Mannino DM, Soriano JB. The natural history of chronic airflow obstruction revisited: an analysis of the Framingham offspring cohort. Am J Respir Crit Care Med. 2009;180:3-10.

3. Brandenberger C, Muhlfeld C. Mechanisms of lung aging. Cell Tissue Res. 2017:367:469-80.

4. Yu H, Jiang S, Land KC. Multicollinearity in hierarchical linear models. Soc Sci Res. 2015;53:118-36.

5. Tsagris M, Pandis N. Multicollinearity. Am J Orthod Dentofacial Orthop. 2021;159:695-6.

6. Kreuter M, Lee JS, Tzouvelekis A, Oldham JM, Molyneaux PL, Weycker D, Atwood M, Kirchgaessler KU, Maher TM. Monocyte count as a prognostic biomarker in patients with idiopathic pulmonary fibrosis. Am J Respir Crit Care Med. 2021;204:74-81.

\section{Publisher's Note}

Springer Nature remains neutral with regard to jurisdictional claims in published maps and institutional affiliations.
Ready to submit your research? Choose BMC and benefit from:

- fast, convenient online submission

- thorough peer review by experienced researchers in your field

- rapid publication on acceptance

- support for research data, including large and complex data types

- gold Open Access which fosters wider collaboration and increased citations

- maximum visibility for your research: over 100M website views per year

At BMC, research is always in progress.

Learn more biomedcentral.com/submissions 